Article

\title{
Expanding the Scope of Sustainability Planning: Lessons from Stockholm's Congestion Charging Policy
}

\author{
Amy Rader Olsson ${ }^{1, *}$ and Diane E. Davis ${ }^{2}$ \\ ${ }^{1}$ Swedish Centre for Innovation and Quality in the Built Environment, SE-111 51 Stockholm, Sweden; \\ E-Mail: amy.rader.olsson@iqs.se \\ 2 Department of Urban Planning and Design, Graduate School of Design, Harvard University, Cambridge, MA 02138, USA; \\ E-Mail: ddavis@gsd.harvard.edu \\ * Corresponding author
}

Submitted: 10 May 2017 | Accepted: 21 September 2017 | Published: 27 October 2017

\begin{abstract}
In 2007, after years of unresolved debate, the Swedish parliament approved a congestion charge for Stockholm applied to cars crossing the city's inner boundary. Since its introduction, congestion charging has led to an even more lasting reduction of car trips to the city center, in part because the policy generates revenues for financing new subway extensions and uses these same resources as the basis for negotiating new transit oriented housing in subway extension areas. As such, congestion charging is arguably as much a sustainable housing solution as it is a narrowly defined transit policy for reducing automobile congestion or pollution. This article investigates how and why Stockholm, despite considerable political conflict, technical complexity and negative public opinion, was able to turn a long-standing and controversial debate over moderating automobile traffic via tolls into widespread support for a national congestion tax, which itself laid the groundwork for a more expansive sustainability agenda. It further suggests that only when congestion charging was strategically reframed and widely recognized as addressing the concerns of multiple and competing constituencies, did efforts for its adoption translate into larger sustainability gains.
\end{abstract}

\section{Keywords}

congestion charging; innovation; land-use policy; planning; politics; transport; urban sustainability

Issue

This article is part of the issue "Social Ecology of Sustainability", edited by Stephen Wheeler (University of California, Davis, USA), Christina Rosan (Temple University, USA) and Bjoern Hagen (Arizona State University, USA).

(C) 2017 by the authors; licensee Cogitatio (Lisbon, Portugal). This article is licensed under a Creative Commons Attribution 4.0 International License (CC BY).

\section{Introduction}

In June 2007, Stockholm introduced a congestion charge for vehicles crossing the city's inner boundary to reduce traffic flows into central city areas and fund badly needed new capital investments. The decision followed a sevenmonth trial and a public referendum. Today, Stockholm is known world-wide for the successes of its congestioncharging program and its early adoption of a policy which has contributed to its reputation as one of the most sustainable cities in Europe. Congestion charging is now accepted by a broad group of stakeholders, including those who ardently fought the introduction of such measures for close to forty years. Moreover, the revenue generated by the charge is now funding subway extensions by negotiating with local communities, who in return for these investments in infrastructure agree to provide transit oriented new housing. Thus, congestion charging has increased local authorities' political capacity to link housing and transportation planning to support sustainable growth.

This case study investigates how, why, and in what ways governing authorities in Stockholm reversed four decades of opposition to congestion charging, bringing 
Green Party advocates, Moderate, Social Democratic, and Liberal Party protagonists together to support this policy despite years of political conflict, considerable technical complexity, and initially negative public opinion. The narrative presented here is based on a review of historical documents, plans and reports, complementary date on historical population and income trends, and interviews with leading politicians, civil servants and NGO representatives, both active and retired. Of 21 total interviews, 14 were undertaken in 2014 based on an interview guide. Other individuals were interviewed as part of the process of determining relevant transportation decisions. During a return visit in 2015 nine additional interviews were conducted, several new actors were interviewed, and some additional contacts were re-interviewed (a full list is available upon request).

In this article we investigate the historical evolution of political support for and against congestion charging in the context of institutional relationships at the municipal, regional and national levels. Our aim is neither to evaluate the transit implications of congestion charging nor offer a new interpretation of the operation of the trial experiment that led up to the public referendum and its electoral success, two topics already well addressed in the literature (Eliasson, Hultkrantz, \& Rosqvist, 2014; Gullberg \& Isaksson, 2009). Rather, we are interested in the temporal and strategic process through which the policy was ultimately recast as contributing to more than transit priorities, as well as what role planners, politicians, and even the private sector played in crafting a reframing which effectively linked congestion charging to other urban challenges such as housing and environmental protection.

Recent work in the transport field has investigated the intra- and inter-bureaucratic conversations that produce policy change within institutions and in particular a shift in focus from transit to mobility. For instance, Hull (2007) explores the organizational and institutional dimensions of policy change and how they are marshaled to produce more sustainable transport policy. Battilana, Leca, and Boxenbaum (2009) have likewise argued that "institutional entrepreneurship" is key to changing the policy mandates within governing institutions. Along the same lines, the international NGO responsible for much of the policy agenda setting in the field of transport, ITDP (International Transport and Development Policy), has recently enshrined a similar rhetorical shift by turning attention away from mobility and more towards access.

We build on this thread in the literature but also move beyond it. In addition to expanding our understanding of congestion charging as having urban sustainability implications beyond mobility because of its im- pact on land-use, we examine the ways in which a negotiated reframing of the benefits of congestion charging by stakeholders both outside and inside bureaucratic institutions and across various political parties has played a critical role in effectively recasting the housing-transport nexus. All this leads us to suggest that the analysis and evaluation of congestion charging must be understood not merely in terms of its mobility impacts but also in the context of larger, more politically and strategically coordinated infrastructural imperatives necessary for producing sustainable cities. ${ }^{1}$ Furthermore, by showing that the reframing of congestion charging involved both national and city leaders and their constituencies, a fact reinforced by the designation of congestion charging as a national tax, we are able to move beyond the biases in much of the policy analysis literature-transport or otherwise-that assumes that the jurisdictional domains of policymaking are either local or national. In this instance, ${ }^{2}$ it was the shared responsibility across governance scales that set into motion an alternative framing of the value of congestion charging, and that ultimately led to its more expanded and transformative impacts with respect to urban sustainability.

\section{Background: The Swedish and Stockholm Context}

Sweden is a Western parliamentary multiparty democracy, with universal suffrage and elections at the national, regional and municipal levels on the same day every four years. It is often said that Swedish voters choose a party rather than an individual candidate, though dynamic and charismatic politicians have boosted political parties in Sweden as elsewhere. In contrast to nations with presidential rule and/or Anglo-Saxon traditions, Swedish politics reflects collective decision-making at all levels; leading Swedish decision-makers to not have the status of say the governor of a US state or the Mayor of London. Accordingly, the decisions described in this case were made by the 101-member Stockholm City Council, the county council assembly and the national parliament. The congestion charge decision in 2006 was a national level tax which required a formal decision of the Swedish parliament.

Many associate the Swedish brand of social welfare policy with the long period of Social Democratic Partyled government for several decades starting in the mid 1920's. In fact, in Stockholm the balance of power between the left and right party blocks has shifted back and forth several times. However, shifts between governing coalitions have in general not paralyzed efforts to adopt new policies and implement major new investments. Part of the reason for this may be that the pe-

\footnotetext{
${ }^{1}$ For more on the importance of conceiving of integrated urban infrastructures as the key to building sustainable cities, see Bonilla and Zapparoli (2017).

${ }^{2}$ In an article by Brian Holland (2015, p. 125), the argument is made that scholarly research on policy design rarely "reflect(s) a discussion of the impact of where programs or initiatives are implemented," and that only institutional analysis will yield possible answers to the "where" question. He further argues the importance of understanding the reasons why different scales of government might prioritize people versus place, economic versus social, or publicly versus privately led dimensions of policy. Such claims are interesting for our analysis here, because a reframing of congestion charging through local and national collaboration allowed a discussion of all of these dimensions simultaneously.
} 
riod between about 1930 and the mid 1960's was one in which there was consensus between the Social Democratic Party and the Liberal party regarding priorities for social welfare achieved through the redevelopment of the built environment based on modernist and functionalist principles. Another explanation for Stockholm's ability to achieve transformative urban development despite differences in political opinion may be the Swedish culture of compromise. Although this is often equated with cultural values favoring consensus, it may be more closely linked to a pragmatic approach to political decision making.

Both functionalism and pragmatism contributed to a Swedish approach to urban development that during certain historical periods has seen transportation and land use for housing and commercial use as intertwined. It was also reinforced by institutions such as multiparty and multi-sector national evaluations and committees at both the national level and in Stockholm (and later, at the metropolitan level). The national evaluations and local and regional plans analyzed for this study all reflect an understanding of functional links among geographies and sectors and are typically the joint responsibility of politicians, civil servants and experts in planning, transport, real estate, public works and finance.

Stockholm's extensive and high quality public transit system, including the metro (tunnelbana) built and extended since the 1940's, emerged from precisely this logic. Since its construction, the subway has contributed to a high share of public transport trips even before the congestion charge was introduced; currently over 70 percent of all trips within the city, 60-65 percent to and from the city centre and about 35 percent of trips within the region as a whole, suggest a high share of transit in total trips by international standards (for current statistics from the City of Stockholm see Stockholms Stad, 2016).

As a consequence of the various driving forces influencing land-use, the population of the inner city started falling in the 1940's and the population of the city in the 1960 's. The fraction of Stockholm's population living in the inner city fell from 78 to 35 percent between 1940 and 1980 and the fraction living in the city, decreased from 67 per cent in 1950 to 42 percent in 1980 whereupon the ratio stabilized. In 2017 slightly more than 41 percent of the region's population lived within the City of Stockholm (Statistics Sweden, 2017).

The expansion of the subway system offered superior, low cost accessibility to a much larger geographic area and as such greatly increased the size and spread of the functional metropolitan region (Börjesson, Jonsson, \& Lundberg, 2013). In Stockholm this tendency was arguably reinforced by policies that provided families of average income with larger dwellings of a higher standard while simultaneously safe-guarding the inner city from high-rise apartment blocks (see Gullberg \& Kaijser, 2004; Malmsten \& Carle, 2007; Sidenbladh, 1981).

\section{Congestion Charging in Stockholm}

Against this backdrop, the introduction of congestion charging both revealed some of the same financial dilemmas and political tensions that marked early debate over the expansion of the subway system, even as it connected the fate of congestion charging to yet another politically contentious transportation conflict emerging in later decades: what to do about growing automobile expansion. The sections that follow describe the decision to introduce congestion charges in Stockholm in light of these historically specific dilemmas; first as a means of expanding an original proposal for toll roads; second as a full-scale experiment (decision 2002; trial 2005-2006) intended to reduce automobile traffic and enhance the use of public transportation, including the subway; and finally as a permanent national tax (decision 2007; extended 2013) that laid the foundation for connecting transport to urban land-use in ways not that dissimilar from decades earlier discussions surrounding the subway.

\subsection{Precedents and Forerunners}

Road charges - not congestion charges-had been discussed for years and were thoroughly analyzed and proposed in national reviews of metropolitan policy in the late 1980's (Swedish Government Official Reports SOU 1989:67-70, SOU 1989:109-112, SOU 1990:20 and SOU 1990:32-36). When the national government opened negotiations with the leading political parties at the local and regional authorities in the Stockholm region for a comprehensive investment package in road and rail, road tolls were formally introduced. ${ }^{3}$ Several of the parties participating in the first round of negotiations were positive to the idea of road charges (Social Democrats, Liberals, Green Party, Stockholm Party, Center Party) but the powerful Moderate Party was firmly against the charges unless they were earmarked for new roads. In Spring 1992 the majority parties remaining in the negotiation leading to the so-called Dennis Agreement (Social Democrats, Moderates, Liberals) said yes to the road charges, contingent on the idea that the revenue would be used exclusively to fund the new roads. "One reason for that the moderates' hesitancy was overcome was surely that they did not see any alternative to financing the road projects they most prized." (Malmsten \& Carle, 2007 , p. 55 , author's translation). Although this was a road toll and not a congestion charge per se, the effect of a new toll to reduce total vehicle miles travelled and to achieve a better spread of traffic to avoid congestion peaks was discussed early on.

When the national government tore up the Dennis Agreement in 1997, plans to introduce road charges in Stockholm were once again tabled. Yet interest in road charges and congestion charges remained. During the

\footnotetext{
${ }^{3}$ This negotiation is popularly known as the Dennis negotiations, named for national negotiator Bengt Dennis.
} 
15 years from the late 1990's Sweden noticed international experiments with charges in Oslo, Singapore and London which were cited by many of those interviewed as important predecessors to Stockholm's experience that gave the idea legitimacy in political circles and, eventually, for the population as a whole. Foreign examples affected public opinion, but also helped individual leaders hone their strategies. Åsa Romson of the Green Party notes that a study trip to Edinburgh during this period was influential; she realized that road charges had only been understood by the public as an economic burden and this prompted her to think about how to communicate the benefits of improved accessibility and economic savings (from e. g. not needing more road space) (interview, May 28, 2014). The Dennis Agreement describes road charges to finance the unbuilt sections of the Ring and for the outer bypass (Västerleden). ${ }^{4}$ This had always been an uneasy and brittle compromise since the Moderates were basically against road charges in all forms, the Social Democrats were against the eastern section of the Ring and the Liberals were against the outer bypass. So when the national government withdrew its support for the package, all bets were off. Yet ten years later a fairly advanced congestion charging tax had been made permanent and by all accounts has received broad (if grudging) acceptance from a wide range of constituencies. How this happened a lot to do with a changed political context in the early 2000's.

\subsection{The 2002 Elections}

During the 2002 election campaign, the environmental lobby had become more organized and was able to highlight the role of road charges in reducing congestion, improving local air quality, reducing carbon emissions, and potentially avoiding the cost and effort to build a western bypass (whose estimated budget increased with every new evaluation and showed no signs of plateauing). On the other hand, there was still considerable support for building new roads as the best way to provide a lasting solution to congestion in the central parts of the city. Even among parties positive to using road charges as a demand management policy, the focus of the argument was somewhat different. Stockholm's environmental director Gunnar Söderholm notes that "The Social Democrats underlined the air quality improvement more than congestion (relief), and the Green Party underlined the decrease in congestion more than the air quality. But this is quite logical. To the Social Democrats, this was not an alternative to new roads but rather a complement. But for the Green party the main issue was, if we can reduce congestion we can avoid new roads, the present capacity will be enough to handle the traffic. They wanted to minimize the number of cars, fossil fuel driven but also the car itself. That was not the case for the Social Democrats - the car has always been a symbol of social welfare and economic growth." (Gunnar Söderholm, interview).

The 2002 election campaign was in full swing in Summer 2002 and the Social Democrats in Stockholm were eager to regain power from the right-wing coalition, as were their party colleagues at the county and national levels. Leading Stockholm Social Democrat Annika Billström was interested in the potential of congestion charging but advocated postponing implementation of a congestion charge. During the election campaign of 2002 , she swore not to introduce congestion charges during the next term if elected. However, directly after the Social Democrats won the election (local, county, and national) Billström was more or less ordered to introduce a full-scale charging experiment by her national government party colleagues. Billström faced a storm of criticism for having broken her promise and according to many of those interviewed, her ability to lead the city was compromised. On the other hand, it was the only way for her to form a majority in the city council and assume leadership (Bosse Ringholm, interview, 2014). Billström used the opportunity to ask the national government for co-funding for a congestion charge trial. She also demanded a secretariat for the "environmental charge" (Miljöavgiftskansli) to be created directly under her to manage the trial.

The Social Democrats were after the 2002 elections the largest party in the national parliament and were eager to maintain power by forming a multi-party coalition government, but this required the active support of the Greens, who, with 17 seats, now had swing vote power. The Green Party representatives demanded a promise to test a full-scale congestion charging scheme in Stockholm-comprising (almost) all access roads to Stockholm but with a strictly defined trial period-noted by many of those interviewed as critical to its eventual success.

The 2002 elections had also given the Greens swing vote power within the Stockholm City Council and the County Council. This made local approval of a congestion charging trial essentially unavoidable, even for the most avid opponents, who nevertheless turned their attention to efforts to delay tactics, including legal appeals of the many details as part of the decision. In the end, it was a seven-month trial instead of a multi-year trial. Much of the legal controversy had to do with whether or not it was possible to introduce a local fee, which would require a change to the Swedish Constitution. ${ }^{5}$ Taxis and other commercial vehicles were exempt from the tax as were alternatively fueled vehicles-a selling point for green cars that had such dramatic effect on sales of ethanol bi-fueled vehicles in particular that it has

\footnotetext{
${ }^{4}$ When the national government finally approved the congestion charging scheme the revenues were (informally) promised (though not formally earmarked) for building the western bypass, the part of the road transportation package in which the national government arguably had the strongest national interest because it facilitated both metro area accessibility as well as national corridors linking Northern and Southern Sweden.

${ }^{5}$ Such a change was made seven years later.
} 
since been revoked to ensure that revenues can remain high and congestion low.

\subsection{The First Trial}

To the surprise of many, the chaos predicted by congestion charging opponents did not materialize. On its first day, the traffic volumes on the gateways to the city decreased by $20-25 \%$. Despite the shortened trial period, the years of planning paid off and the trial itself was relatively smooth. However, issues regarding its form, function and timing remained unresolved. Tax or fee? Locally or nationally determined and administered? Who pays, and to whom would the revenues accrue? How would they be used? The national government and the parliament held firm; according to the Swedish Constitution a congestion charge is a national tax over which the parliament has decision-making authority and indeed, did not have the legal authority to delegate to the government or to a municipality. ${ }^{6}$ This means that strictly speaking, the Stockholm region can make no claims on the revenues from the congestion charge. However, all those interviewed reported a common understanding of charge revenues as financing transportation improvements in Stockholm. This is strengthened by public statements from national government politicians noting the tax as an important national contribution to Stockholm's transportation infrastructure.

Congestion charging in Stockholm was, however, not a matter where every party leader could count upon unanimous support among party members. On the contrary, there were deep splits within some parties at the city and county levels. Interviews (e.g., Bo Malmsten, Klas Thorén, and Bosse Ringholm) indicate that the Social Democrats at the city level were positive to congestion charges but those in Stockholm's suburbs were opposed. Some of this had to do with actual uncertainty regarding effects on economic growth and the distribution of costs and benefits. Some uncertainty was more tactical in nature. Would cooperation and compromise with other parties strengthen their position, or would they "give away the store" in the process? A similar type of uncertainty had to do with signals between the local and national levels. Would an acceptance of congestion charges free up additional resources for Stockholm's road infrastructure, or give the national government an excuse to reduce the annual transportation subsidy-essentially using the congestion charging revenues for other national priorities? Interviews, as well as reviews of public statements during the 2002-2007 period indicate that many political leaders were attempting to both calm their base constituencies (that may or may not want the tax, or may or may not want revenues from the tax to facilitate the approval of new motorways) but also leave the door open for compromises with other parties and other political levels.

\subsection{A Political Gamble: The Referendum in Stockholm}

The move from mandated large-scale experiment to potentially permanent national tax was bound up with promises from both the national and local governments to hold a local referendum on the issue of a congestion tax. ${ }^{7}$ In the City Hall, the Moderates and Liberals were opposed to the congestion tax and found popular support against road charges in any form. Annika Billström (Commissioner of Finance) and the rest of the city leadership, including representatives of the Green party, accepted the idea of holding a referendum, but not the timing. They decided that the referendum would not be held until Stockholm had the benefit of experiencing a fullscale experiment. The referendum was therefore held simultaneously with the general election in 2006. Billström promised that although the referendum was formally still only advisory, the city would respect the decision of the electorate-within the City borders.

This proved important in several respects and provides a clue to the aspects of leadership in Stockholm that may be essential to understanding this case. Agreeing to respect the results of a referendum was politically risky-polls at the time showed that a majority of Stockholmers were clearly against the charge. ${ }^{8}$ Nevertheless, Billström reasoned that agreeing to a referendum would dampen the powerful criticism she was subject to from other parties, from the press and indeed from some of her own constituency. She had been compelled to break a promise to wait with a full-scale test-but now demanded that a referendum be held once the voters had a clear sense of how it affected them, both positively and negatively. This also gave transportation planners and administrators time to focus on the immediate improvements that could be made in other areas, such as significantly expanded bus service and new subway cars - that showed that voters were "getting something" from the charge-even if this was strictly speaking not the case. So, promising to hold a referendum was relatively unproblematic, and promising to follow its result was risky but could effectively counteract arguments that she was unresponsive to her constituency. Only the results of the referendum held in the municipality of Stockholm would count. Results from surrounding communities would be considered, but not allowed to determine what the City of Stockholm would propose to the national government and parliament to make the charge permanent.

\footnotetext{
${ }^{6}$ This paragraph of the Constitution has since been modified. Since 2011, the Swedish parliament may delegate such decisions to the government or to a municipality but it is stated that such a delegation right should be used restrictively.

${ }^{7}$ Referenda have always been advisory, i.e. non-binding, in Sweden. If a minimum of $5 \%$ of eligible voters demand a referendum, local governments are compelled to administer it.

${ }^{8}$ Polls taken when the congestion charge trial had been announced, but was not yet underway, showed $52 \%$ percent in favor in late 2004 , but only $43 \%$ by late 2005 . However, towards the end of the trial public support had increased to $54 \%$, a remarkable shift that underscores the importance of helping users experience actual effects of such a policy (Hårsman \& Quigley, 2010).
} 


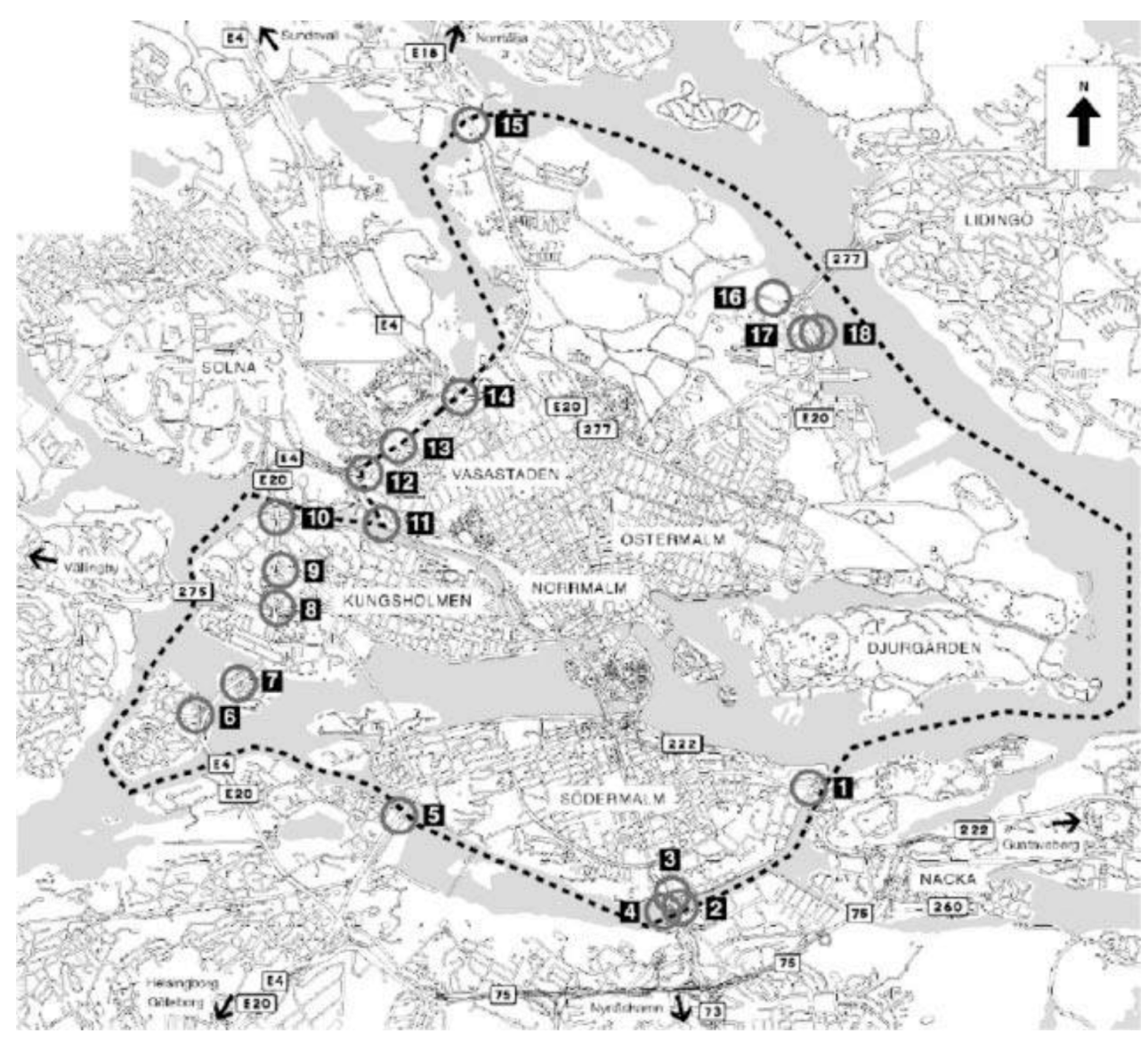

Figure 1. The congestion charge zone and electronic payment gateways. Many gateways have several hundred years of history as tolled entry points for goods into the city. It is also no accident that all of the actual charging points (including the physical infrastructure itself) are on Stockholm City land. To site gateways in other municipalities would have required negotiating land use rights with additional communities and it was feared that surrounding municipalities could use land use monopoly power to block the trial (Hårsman \& Quigley, 2010; Swedish Road Administration, 2005).

The gamble paid off. The referendum in Stockholm showed a clear majority in favor of continued congestion taxes, with support strongest in the inner city. Perhaps predictably, among those in the surrounding communities that held a vote, a clear majority remained against. Yet because the decision whether or not to move forward was contingent on the municipality vote, these results did not undermine the mayor's efforts to move forward with congestion charging. This is not to say that the negative results of the referendum outside the city were inconsequential. Not too long after the referendum, the 2006 election put the right bloc ${ }^{9}$ back in powerin the parliament, the county council and in Stockholm with enough of a majority that they could build a coalition government without the Green Party. The left bloc had won the referendum regarding congestion charging, but lost its seats at all levels of government. Whether or not this was related to congestion charging more than other electoral issues is hard to say, but as a single-issue, the political impact of prior support for or opposition to congestion charging was not entirely obvious with re- spect to the newly established electoral power balance. As suggested by Hårsman and Quigley (2010) the causation goes in two directions: those with strong opinions about congestion charging might have voted for a party sharing their opinion and those having strong preferences for a political party may have disregarded their opinion about the charging system.

The City Council's new Moderate majority leadership was now faced with a tricky situation, described by party colleague Carl Cederschiöld this way: "the voters gave the right bloc a clear majority; and although the moderates and liberals (Folkpartiet) were clearly against the congestion tax, they now had control of the city hall. At the same time, while Stockholmers voted $54 \%$ for the congestion charge, $80 \%$ of the people that had voted in surrounding communities were against. ${ }^{10}$ Furthermore, within the alliance (Moderates, Liberals, Christian Democrats, Center) we had a split, the Center party wanted the tax. We needed to unravel that knot, so we came up with a clever solution. We four parties wrote a guest editorial in DN (Dagens Nyheter, Stockholm's

\footnotetext{
${ }^{9}$ Moderate, Liberal, Center and Christian Democratic parties

${ }^{10}$ This is important because the local, regional and national representatives of the same parties were not necessarily in agreement and neither were those that voted for them.
} 
largest daily newspaper) about a week before we were scheduled to assume governance of the city and announced that there would be a permanent congestion tax from July 12007 . We had to do it before we assumed power, we had to pre-empt the discussion before it completely got out of hand."

The text to which Cederschiöld is referring (Reinfeldt, Olofsson, Leijonborg, \& Hägglund, 2006) was an important strategic move for the incoming coalition government. First of all, the editorial was signed by the leaders of the four parties that called themselves the "alliance" at the national level: incoming prime minister Fredrik Reinfeldt, (Moderate), Maud Olofsson (Center), Lars Leijonborg (Liberal Folkpartiet) and Göran Hägglund (Christian Democrat). This is an example of the importance of ongoing communication among party members at the local, regional and national levels. It is also a clear signal from the new national government that they intended to set the agenda for future decisions regarding congestion charging in Stockholm rather than facilitating an independent local decision, notwithstanding the reference to a future decentralization of charging authority to local or regional authorities. ${ }^{11}$ Perhaps even more importantly, the alliance parties re-coupled the congestion charging issue with decisions regarding other major transportation investments, announcing that congestion taxes would be introduced as part of a major transportation policy package negotiated between the local, regional and national levels. This put the western bypass back on the bargaining table, opening negotiation space with more auto-dependent communities surrounding Stockholm for the incoming minister of finance Anders Borg. With one stroke congestion taxes were positioned as a funding mechanism for new roads, the solution with which the right bloc (and the Moderates in particular) had always been most comfortable with. And with this compromise, congestion charging had moved beyond its pilot status into the realm of reality, promoted and institutionalized now by some of the very same political forces that had raised questions about its appropriateness under previous Mayor Billström.

\subsection{Congestion Charges to Fund Subways-And Facilitate Housing}

The discussion about using congestion taxes to fund a range of transport infrastructures made sense to a wide range of political actors, given that Stockholm's population growth had continued unabated since 1981. By the mid-2000's, Stockholm's labor and housing market had outgrown both city and county administrative limits; while economic growth has been even more rapid than population growth, notwithstanding economic downturns and the global economic crisis. Given its expansion,

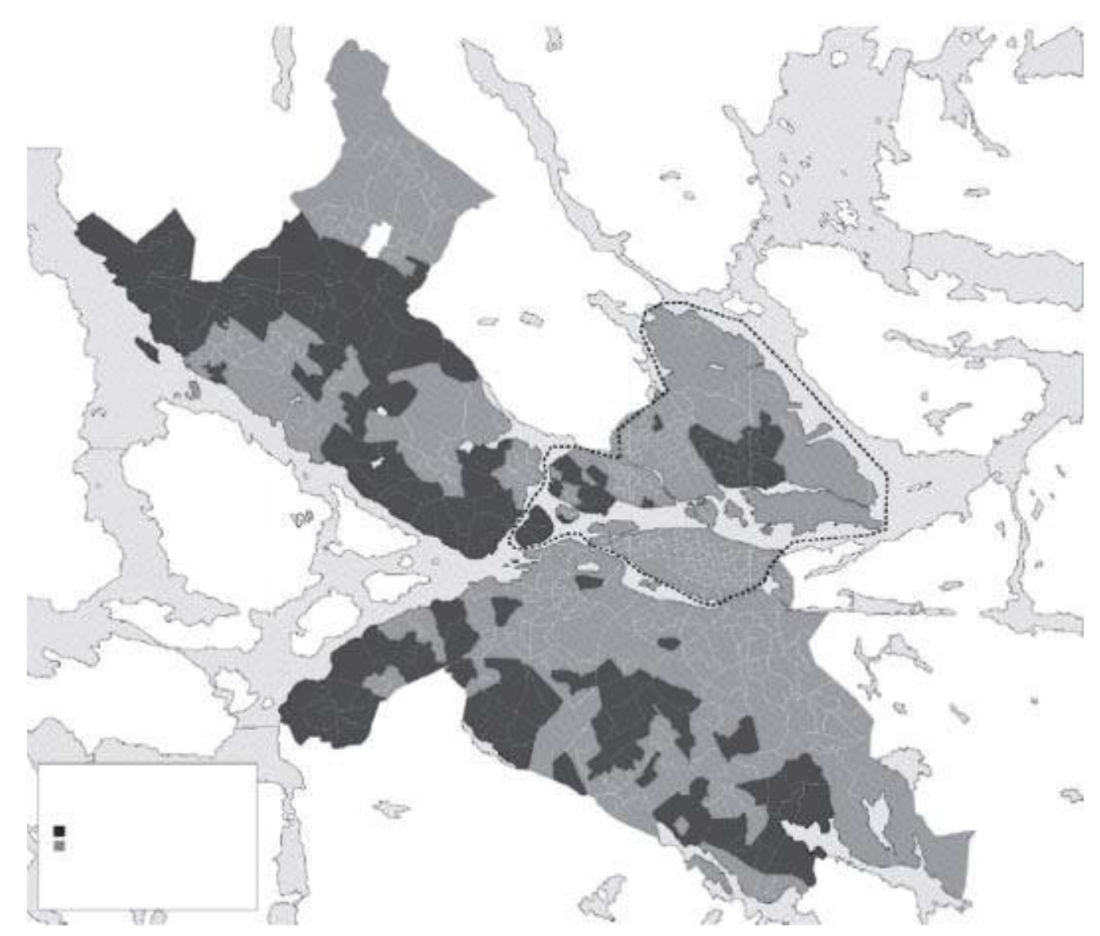

Figure 2. Results from the Stockholm referendum on congestion charging in $2006,52 \%$ for and $48 \%$ against. Note: City of Stockholm residents only; charging cordon noted as a dotted line. "No" districts noted in the darker shade. Those within the cordon were in general far more favorable to the charge than those outside the cordon. Roughly half of the revenues come from residents within the cordon (Hårsman \& Quigley, 2010).

\footnotetext{
10 As of 2017 this has not transpired although several respondents argue that it is "understood" that revenues should in some way remit to the Stockholm region.
} 
many were arguing that Scandinavia's largest city could position itself as a successful model for a European capital city built on innovation, sustainable growth and diversity. This was an argument dear to many in the right-wing bloc. But it would be hard to realize such aims without public investments to facilitate such goals. Among the greatest barriers, as described in a number of reports, including OECD Territorial Review for Stockholm (Organisation for Economic Co-operation and Development, 1999), were those related to housing and transport.

The housing market had both too low a rate of new buildings and a range of institutional factors hindering turnover. The structural problems affecting Stockholm's housing market included the effects of continued rent control policies, tax policies affecting turnover, and low rates of new developments were often attributed to confusing national laws and sometimes local policies. A number of improvements had long been proposed by interest groups and opinion leaders, and there had been some reforms to housing policy and regulation, but many were seen as too politically charged and had not yet been implemented. In the post-2006 electoral environment, however, Moderates saw an opportunity to put these issues back on the agenda when considering whether to proceed with congestion charging, using these issues to widen their coalition of support. By highlighting the importance of explicitly linking extensions of the subway to new housing developments in station areas, advocates of transportation expansion were able to produce broad approval across political blocs in the parliament, county council, and municipalities for more forceful action. ${ }^{12}$ The Moderate Party was, as noted above, in favor of using revenues from congestion charging taxes for building new motorways, but now they changed their strategy. The national government negotiated an agreement regarding both housing and subway extensions including the division of responsibility and regulatory authority among the national government, County Council and municipalities (Stockholmsförhandlingen, 2007). Since that agreement, the congestion charge revenues have increased, due partly to higher charges and partly to the inclusion of additional crossings (Swedish Transport Agency, 2016).

About half of the additional revenues generated from the expanded and raised congestion charges will fund the new subway expansion. The Stockholm County Council will build nine new subway stations and associated rail infrastructure in Stockholm and three neighboring municipalities (Järfälla, Nacka and Solna) during the period 2018-2025. Stockholm and these three municipalities promise that 78,000 new apartments will be built in the station areas (either by municipally owned development companies or by private developers) over a 16-year period. This is roughly twice the number of new apartments built in the entire region in past six years; in other words, it is a major breakthrough in the seemingly in- tractable "chicken and egg" problem plaguing the building of new transport infrastructure (in hope that housing will be built) and new housing (in hope that transport infrastructure will be built).

To the extent that congestion charge revenues are regarded as national level contributions to Stockholm's infrastructure (the charges legally are national taxes), the national level is thus contributing about 70 percent of the cost for the subway extensions and the county council and municipalities for the balance of the capital costs plus some marginal costs for new subway cars and associated infrastructure. If we instead regard congestion charges as a regional contribution (aggregated from individual contributions of which roughly half are Stockholmers and half from the rest of the region), then the proportion of national/local financing is basically the opposite. But either way, the point is that congestion charging is far from a localized policy whose impacts are felt only by Stockholm residents or those driving into the city. Rather, congestion charging has become a transport policy initiative capable of uniting multiple scales of governance around a range of spatial planning and sustainability aims.

\section{Insights from the Stockholm Congestion Charging Experience}

Building on Metzger and Rader Olsson's account of Stockholm's experience with sustainable urban development over the past century (2013), we argue that the contributions of congestion charging to larger urban sustainability goals are the result of critical decisions that laid the pathway for addressing a wide range of infrastructure concerns, ultimately leading to the successful adoption of congestion charging and to a more robust planning process capable of integrating multiple sustainability aims.

\subsection{Linking the What and the Why to Build Support}

Information and awareness-building about sustainability is important, but this case has suggested that such goals must be supported by concrete interventions that directly impact everyday life in the city. Likewise, action without awareness-building can fail if those affected do not understand their purpose. The congestion charging policy in Stockholm tests this hypothesis and suggests a slightly modified formulation, building on recognition of the ways that initial transport policy discussions established strong political positions that ultimately created limits as well as opportunities for consensus.

The idea of road charges in some form had been evaluated, packaged, spun, wrangled and debated by all parties, in Stockholm and at the regional and national levels. Repeatedly, congestion charging failed to win support as purely a revenue source for motorways, or as a demand

\footnotetext{
12 This is essentially a reaffirmation of the principles of the 1952 City plan and the regional plans that followed it. Even the routes of the proposed subway extensions are essentially inspired from proposals and arguments in the 1965 Subway plan, which were not implemented.
} 
management measure. Eliasson (2014) argues that the reframing of congestion pricing as an environmental policy was important to its eventual political and public acceptance. We support this idea but propose that it was a rather longer and more complex process of coupling, decoupling and re-coupling congestion charges with a range of goals such as environmental protection, revenue generation, and even solving acute housing shortages that finally succeeded in breaking political logjams and building local support. A potential consequence of this strategy was that over time, identically articulated congestion charge policies could become different things to different constituencies. This allowed competing interests to agree on one policy but for varied reasons.

For example, the Stockholm Party (locally) and the Green party (nationally, later also locally) chose the single issue of a congestion charging trial as their condition for support and used this to court both the left and the right from the middle. They found a vacuum in local (and later national) politics that could be called "environmental urbanists." In contrast to the "green wave" of decades earlier that equated environmental ideology with living off the land and eschewing capitalism, these new urbanists celebrated the city. The Stockholm Party was focused on both the natural environment and the built environment, and chose niche issues that appealed to the new urban professionals. They attracted voters from the right bloc that were market oriented but wanted more explicit focus on the natural environment, and from the left bloc that were interested in exploring the potential of privatization, support for small businesses and innovation as sustainable development strategies. The Green and Stockholm parties led by cleverly decoupling and recoupling issues. They found a new party platform that appealed to a growing niche in Stockholm's electorate, the environmentally aware urbanite. They decoupled congestion charging from the grandiose and highly interdependent giant transport packages that were moving two steps forward and one step back. They also recognized that their ultimatum should be the demand for a congestion charging trial, full scale but limited, and followed by a public referendum (Romson notes that a 7-month full scale trial was seen as an absolute minimum and that it was important that she rejected a last-minute proposal to limit the trial to only a few parts of the city).

The Green Party (which by the end of the trial had more or less incorporated what was left of the Stockholm Party) hoped that demonstrating that congestion charges would provide lasting congestion reduction without jeopardizing continued economic growth would finally take the motorway plans off the table. Instead, the other major parties set out to "recouple" the increasingly accepted charging scheme back to their old priorities. The right bloc's pre-emptive strike following the 2006 elections, accepting the charges but firmly repositioning them as a funding source for the new roads seems to have been effective. The fact that the national government and Stockholm's municipalities are now using the opportunity to finally make concrete plans for new housing is testament to the importance of re-coupling the congestion charges to development plans for public and private transport, housing and accessibility.

This continuing reframing of the "what and why" of congestion charging may hold lessons for approaching sustainability policy in other cities. The inclusion of road charges in the Dennis package negotiations was an important strategy to build support for a comprehensive transportation package, because it allowed diverse political constituencies to agree on the same package for different reasons. However, it may have also had the effect of reinforcing the idea that road charges (including congestion charges) are a transportation investment and demand management policy as opposed to a sustainable urban development policy. When considered primarily a transportation policy, road/congestion charges are negotiated in relation to other transportation priorities, and local and regional authorities that lack the resources for large capital transportation infrastructure investments are in a difficult negotiating position with powerful national authorities. But when congestion charging is imbued with a dual revenue generation/demand management role, linked more strongly to urban sustainability goals and in particular to housing provision, policy space is opened for more balanced negotiation between the local and national levels. Congestion charging linked not only the "what" and the "why" more clearly, but also the "who".

\subsection{Build consensus or forge ahead?}

Marquis W. Childs' book Sweden: The Middle Way (1936) characterized Swedish politics has been as focused on cooperation and compromise across party lines or as pragmatic and driven by common sense or an engineering attitude to problem-solving. Childs has many followers that underscore the Swedish capacity for consensus and compromise (See e.g., Möller, 2011; Kelman, 2012). The political culture of consensus-seeking and pragmatism has never meant an absence of political differences and political fights. However, fights have more often than not resulted in going "back to the drawing board" for further evaluations and have eventually led to compromises rather than stalemates blocking further actions. Broad consensus can lead to "watered down" sustainability policies that are ineffective as tools for change. In the congestion charging case, however, Stockholm managed to make bold policy and investment decisions without losing sight of the need for compromise and at least some kind of consensus-at least regarding the attractiveness of congestion charges, albeit with different motives and revenue priorities.

Earlier studies of Stockholm's congestion charging experience have suggested that the acceptance of congestion charges can be explained at least in part by the city's high share of public transport users, with median voters in favor of congestion charges due to their potential to 
benefit transit and reduce urban congestion (Armelius \& Hultkrantz, 2006). However, this does not explain why charges were not imposed far earlier. It may be argued that willingness over time to bundle congestion charges with transportation investments that would appeal to inner city transit users as well as regional motorists (in particular by funding the western bypass) demonstrates the importance of compromise and of compensating "losing" constituencies. ${ }^{13}$ This is logical, but does not explain the political courage to announce the full-scale pilot before determining exactly where revenues would be spent. This may illustrate the importance of timing open and closed negotiations; an open announcement of the congestion charge pilot, with simultaneous closed discussions regarding revenues and more comprehensive transportation investment packages.

It is difficult to attribute innovative transport decisions to an individual or a single organization or party; rather, this case reflects the contribution of key individuals-leaders-in achieving support their proposals in the City Council and the national parliament respectively in a specific economic, social and political context. Throughout the process they also needed to convince influential subordinate authorities and associated bureaucrats, and these processes were time-consuming and demanding. Effective leaders had ambitious and visionary goals but also remarkable patience and tenacity. By contrast, when leading politicians and parties sought to force decisions, disable the opposition or set ultimatums they were either typically sent "back to the drawing board" to be reevaluated, discussed again, tested, and-in the case of the congestion charge-re-legitimized by a popular vote.

From studying these differences and the processes that preceded them, we can conclude with some other additional takeaways on the subject of political strategies and tactics necessary to achieve policy success:

- Open and closed negotiations are both useful, but the order of these matters. From this case study, it appears that starting with an open discussion to build consensus and public support and then moving to a closed negotiation to negotiate specific terms can be effective;

- Setting limits on the scope of the negotiation is key. Without limits or trade-offs from the outset, the negotiations run the risk of spiraling out of control. Some of these imposed limits might include Elections or electoral timing, Legislation, Finances, Early commitment to other infrastructure projects, and Physical realities (i.e. Stockholm being surrounded by water);

- Perseverance through periods of uncertainty and divergent opinions is as or more important as per- severance during times of cooperation. Conflict is just as important as consensus, and both are to be expected in an effective negotiation;

- Language is key in building political support. Calling the congestion tax a toll was much less favorable, and the phrasing of the referenda in the surrounding municipalities likely affected how it was perceived. In addition, continuity in language can be similarly important (e.g. the use of the words "negotiation" and "package");

- Piloting or other large-scale experiments can reduce uncertainty regarding effects and therefore allow policymakers to craft compensatory policies within the context of political negotiations.

In policy circles, decisions are often made based on expectations that both physical infrastructure and policy commitment will endure. This is critical in helping individuals evaluate the costs and benefits of a particular policy. However, the long-term impacts of novel, as-yet unrealized policies may be difficult to gauge. This case shows that the city's "full scale experiment" in congestion charging, built on a pilot tested at a scale large enough to reduce various types of uncertainty and build acceptance, but small enough to be dismantled if proven ineffective, was a key determinant of policy success. The congestion charging pilot led to a dramatic reversal of public opinion from strongly negative to positive. It anticipated broader applications of policy and expansions, but took an incremental approach. Congestion charging is now an accepted part of the policy portfolio in Stockholm; it remains to be seen if it will be as successful in other Swedish areas. This follows Eliasson (2014) but adds the idea that the individual experience of voters related to public acceptance is not identical to the political experience of politicians experimenting with various policy incarnations over time and in changing political contexts. But in this case, the positive experience of voters helped change the policy calculation of politicians, thus leading to widespread embrace of congestion charging.

\section{Conclusions}

Although the congestion charging decision played out in a distinctively Swedish context, it involved a complex process of reframing both the problem of congestion and the aims of transport policy in ways that required strategic diplomacy and tactical mediation. Only when it was recast as simultaneously a traffic restriction and a revenue generation measure did it become widely recognized as addressing the concerns of multiple and competing constituencies, thus breaking the long-standing political impasse.

\footnotetext{
13 It may be worth noting that another argument for building the western bypass was to reduce the isolation of the rich north and less wealthy southern parts of the metro region (a long-standing priority for the left leaning parties) and help working families access jobs, schools and local services. It bears underscoring that the working class, generally a strong share of the left bloc's constituency, have in recent decades moved further and further out in the Stockholm region as the processes of gentrification in Stockholm and the near suburbs proceeded. For many residents within the City of Stockholm, the idea of charging the cars coming into the city so as to reduce inner city congestion was attractive, not least if revenues could be used to improve public transportation (either directly, or as a result of not having to use as high a share of national transport allocations for roads).
} 
Through the introduction of congestion charging, Stockholm has experienced major transformations in revenue/financing sources, institutions and the institutionalization of the housing-transport nexus, communication and coordination between the different levels of government, and a certain willingness on the part of both politicians and citizens to make sacrifices on behalf of overall sustainability goals. Just as importantly, the policy's successes have produced a transformation in the ways that transportation policies are now being perceived, far from being seen solely as an enabler of mobility they are now also viewed as a complement to housing (i.e. a mode of infrastructural servicing) and a basis for an integrated regional planning system, the latter of which is perceived as crucial to the achievement of larger urban and national development aims. Likewise, the intensified focus on dense urban living in Stockholm has been made possible by congestion charging, but is also now connected to many other agendas, including economic competitiveness and environmental sustainability. The process followed to arrive at this outcome was marked by successes and failures, not to mention conflict and consensus, all revolving around congestion pricing as a policy as well as over who would get political "credit" for introducing or rejecting this policy.

If we accept that the process is as important as the outcome, knowing exactly which process to follow to keep the idea of congestion charging alive, knowing at what point in time a new framing is necessary, and understanding which organizational or political tactics will help achieve both, will be critical to sustainability outcomes. One might say that after decades of struggle, there is now enhanced planning capacity to have a healthy conversation about urban sustainability in Stockholm, including but certainly not limited to the role of transportation. Hands-down, the capacity to leverage multiple sustainability goals must be considered one of the most important contributions of congestion charging to the field of urban planning, and the reason that other cities should take it seriously.

\section{Acknowledgments}

This research received funding from the project entitled "Transforming Urban Transport-The Role of Political Leadership" (TUT-POL), sponsored by the Volvo Research and Educational Foundations (EP-2012-03) and hosted at the Harvard University Graduate School of Design under the direction of Diane E. Davis. Björn Hårsman, Bo Wijkmark, Anneli Tostar, and Jacob Witzell provided research support. Lily Song, Senior Research Associate for TUT-POL, provided editorial support. The authors are responsible for the facts and the accuracy of the information in the case, which does not necessarily reflect the views of the Volvo Research and Educational Foundations or the Harvard University Graduate School of Design.

\section{Conflict of Interests}

The authors declare no conflict of interests.

\section{References}

Armelius, H., \& Hultkrantz, L. (2006). The politicoeconomic link between public transport and road pricing: An ex-ante study of the Stockholm roadpricing trial. Transport Policy, 13(2), 162-172. doi:10.1016/j.tranpol.2005.11.011

Battilana, J., Leca, B., \& Boxenbaum, E. (2009). How actors change institutions: Towards a theory of institutional entrepreneurship. Academy of Management Annals, 3(1), 65-107.

Bonilla, M., \& Zapparoli, I. (2017). The challenge of financing urban infrastructure for sustainable cities. Washington, DC: Inter-American Development Bank, Housing and Urban Development Division.

Börjesson, M, Jonsson, R. D., \& Lundberg, M. (2013). The long term benefits of public transport: The case of the Stockholm subway system. (Report 2012:5), Stockholm: Expert Group on Public Economics, Ministry of Economic Affairs. (in Swedish)

Childs, M. W. (1936). Sweden: The middle way. London: Faber \& Faber.

Eliasson, J. (2014). The role of attitude structures, direct experience and reframing for the success of congestion pricing. Transportation Research Part A: Policy and Practice, 67, 81-95.

Eliasson, J., Hultkrantz, L., \& Smidfelt Rosqvist, L. (Eds.). (2014). Stockholm congestion charging trial [Special issue]. Transportation Research Part A: Policy and Practice, 43(3), 237-310.

Gullberg, A., \& Isaksson, K. (Eds.). (2009). Congestion taxes in city traffic: Lessons learnt from the Stockholm Trial. Lund: Nordic Academic Press.

Gullberg, A., \& Kaijser, A. (2004). City-building regimes in post-war Stockholm. Journal of Urban Technology, 11(2), 13-39.

Hull, A. (2008). Policy integration: What will it take to achieve more sustainable transport solutions in cities? Transport Policy, 15(2), 94-103.

Holland, B. (2015). Typologies of national urban policy: A theoretical analysis. Cities, 48, 125-129.

Hårsman, B., \& Quigley, J. M. (2010). Political and public acceptability of congestion pricing: Ideology and self interest (Working paper No. W09-005). Berkeley, CA: Berkeley Program on Housing and Urban Policy,

Kelman, S. (2012, December). Sveriges framtid behöver kompromissviljan. Dagens Nyheter. Retrieved from http://www.dn.se/kultur-noje/kulturdebatt/sveriges -framtid-behover-kompromissviljan/

Malmsten, B., \& Carle, M. (2007). From Hörjel to Cederschöld -40 years of negotiations between the national government and the region. (Report 2007:4). Stockholm County Council, Office of Regional Planning and Transportation. (In Swedish) 
Metzger, J., \& Olsson, A. R. (Eds.). (2013). Sustainable Stockholm: Exploring urban sustainability in Europe's greenest city. Routledge.

Möller, T. (2011). Svensk politisk historia: strid och samverkan under tvåhundra år. Lund: Studentlitteratur.

Organisation for Economic Co-operation and Development. (2006). OECD territorial reviews: Stockholm, Sweden 2006. Paris: OECD Publishing.

Reinfeldt, F., Olofsson, M., Leijonborg, L., \& Hägglund, G. (2006, October 1). Vi säger ja till trängselskatten för att finansiera kringfartsleder. Dagens Nyhete. Retrieved from http://www.dn.se/debatt/vi-sager-jatill-trangselskatten-for-att-finansiera-kringfartsleder/

Sidenbladh, G. (1981). Planning for Stockholm 19231958. (in Swedish). Stockholm: Stockholmia förlag
Stockholmsförhandlingen. (2007). Trafiklösning för Stockholmsregionen till 2020 med utblick mot 2030 [A transportation solution for the Stockholm Region by 2020 with a perspective to 2030]. Gävle: Lantmäteriverket.

Stockholms Stadt. (2016). Andel kollektiva resor. Retrieved from http://miljobarometern.stockholm.se/ trafik/kollektivtrafik/andel-kollektiva-resor-dygn/

Swedish Road Administration. (2005). Nord-sydliga förbindelser i Stockholmsområdet. Stockholm: Vägverket Region Stockholm.

Swedish Transport Agency. (2016). Congestion taxes in Stockholm and Gothenburg. Retrieved from http:// transportstyrelsen.se/en/road/Congestion-taxes-inStockholm-and-Goteborg/

\section{About the Authors}

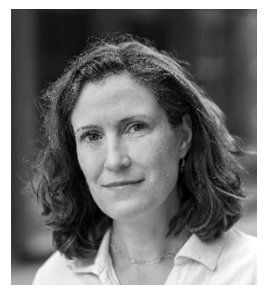

Amy Rader Olsson is a researcher in urban planning and research program director at the Swedish Centre for Innovation and Quality in the Built Environment. Her research focuses on planning institutions for cooperation, conflict resolution and public engagement. She has served as a special evaluator to the Swedish government and advisor to several national agencies including the Swedish Transport Administration and the Swedish Energy Agency.

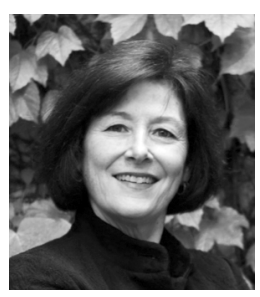

Diane E. Davis, Charles Dyer Norton Professor of Regional Planning and Urbanism, and Chair of the Department of Urban Planning and Design, is author of Urban Leviathan: Mexico City in the Twentieth Century (Temple University Press, 1994), Discipline and Development: Middle Classes and Prosperity in East Asia and Latin America (Cambridge University Press, 2003) and Cities and Sovereignty: Identity Politics in Urban Spaces (Indiana University Press, 2011) to name a few. Her published works examine the relations between urbanization and national development, the politics of urban policy, urban governance, and spatial conflicts. Her current work focuses on the future of cities in an era of rapid technological innovation, climate change, and new forms of sovereignty. 